\title{
From Tolerance to Repression and Back: Herbert Marcuse and the (II)-Liberal Politics of Inclusion \\ Morgan Shipley
}

This is not an essay about tolerance as an end in itself; nor does it search for ways to extend the current model of tolerance in the post-industrial world. Rather, this essay explores the implosion of tolerance politically in the United States, how in the name of tolerance, according to Herbert Marcuse, "its most effective manifestations serv[e] the cause of oppression," and the ways that tolerance can regain its (potentially) progressive nature. This essay attempts to uncover the promise of tolerance in order to create the theoretical and physical space needed for honest and progressive dissent to flourish and function amongst a democratic polity jaded by the failed promises of Western Liberalism.

For Marcuse, "it was the openness to alternatives proffered by a broadly practiced and non-repressive tolerance which was a precondition of freedom and veri-si-mi-litude." If non-repressive, tolerance becomes the "precondition of freedom;" however, as this article develops, by connecting tolerance to economic freedom and State power, tolerance emerges as a system of perpetual repression. As evident as the State may desire it to seem, tolerance as a political tool does not unequivocally lead to inclusive policies, but rather, in the modern American context, allows the political machinery to pursue policies of war and torture that essentially ignore the plight of the average citizen domestically and internationally, in the name of protecting and maintaining American, liberal values. Herbert Marcuse's essay "Repressive Tolerance" creates a glimpse into a democratic polity capable of realizing utopic principles, yet essentially shutout by the very principle that should lead the way. While historically tolerance led to more inclusive social principles, culturally it continues to define the dichotomy of "us vs. them" necessary politically for a country to carry on a subversive war that, until recently, was not only tolerated by the American citizenry, but applauded. ${ }^{3}$ In order to break loose from oppressive behavior and regain the truly liberating and radical dimension of tolerance, we must, as Marcuse suggests, excavate through a system "which fosters tolerance as a means for perpetuating the struggle for existence and suppressing the alternatives."4 Only then can American society regain its footing and ability to operate within an oppositional system that seeks to transform the repressive policies of modern, liberal tolerance into a new understanding of tolerance that 
leads to a more inclusive and humane society. As Marcuse advocates, agents trapped within a repressive model of tolerance must respond repressively in order to establish a new understanding of tolerance that leads to a more inclusive, progressive and humane society.

\section{Identifying the Problem: The Interchangeability of Liberalism and Tolerance}

Grasping the bureaucratic manifestation of a tolerance that functionally seeks to include all in the broadest sense, Marcuse's analysis of repression and tolerance demands that we re-engage principle understandings of these terms in a liberal polity. In modern, political constructions, liberalism and tolerance become interchangeable, one producing the condition for the other, and vice versa. While this interchangeability suggests a strong, progressive understanding of freedom - a self-sacrificial denial of absolute, sovereign authority and freedom - pragmatic fears for actual, non-coerced cooperation and moderation push the individual into the protection of societies, derived not from selfmoderating freedom, but from the interchangeability of liberalism (economic and individual liberty) and tolerance. While the exact tenets of liberalism can be debated, this paper uses John Locke's broad, dualistic liberal model: freedom of conscience or thinking and economic freedom. ${ }^{5}$ In Louis Hartz's analysis of America's liberal tradition, the birth and growth of American politics occurred according to Locke's understanding of a liberal consensus without ever experiencing

“'a liberal movement' or a real 'liberty party' in America: we have only had the American Way of Life, a nationalist articulation of Locke which usually does not know that Locke himself is involved [...] here is a doctrine which everywhere in the West has been a glorious symbol of individual liberty, yet in America its compulsive power has been so great that it has posed a threat to liberty itself.", This narrowing of the political landscape is nothing new in Lockean liberalism where a real seed of conformity and control exists.

In the liberal world, according to Locke, individuals elect to leave the state of nature and enter political society to secure certain freedoms. In the state of the nature, the natural liberty of the individual "is to be free from any Superior Power on Earth, and not to be under the Will or Legislative Authority of Man, but to have only the Law of Nature for his rule." While this law of nature produces ultimate freedom, it also eliminates all methods of 
social control beyond mutual cooperation or violence. As Thomas Hobbes more strongly argues, without a common power to maintain the law of nature, "every man is Enemy of every man." ${ }^{\prime 8}$ While Locke understands this threat in terms softer than Hobbes's state of perpetual war, he still recognizes a need for self-preservation, not unadulterated freedom. For Locke, this urge inevitably emerges and reorders life from within the state of nature fear and the need for self-preservation functionally nudge the individual away from pure freedom and into the realm of obedience. While obedient to a consented-to sovereign, in Locke's ideal-liberal model, this is not a strict moment of absolute submission, but a progressive and constructive step in securing and maintaining liberty.

In order to emerge from the state of nature while retaining a memory or sense of freedom, political society requires both a creative step and a coherent moment of consent in which the individual transitions from the state of nature into a recognizable political State. In creating political society, the "Sword is not given the Magistrate for his good alone," Locke writes, but for the "Preservation of every Man's Rights and Property, by preserving him from the Violence or Injury of others." In this moment, the individual performs two simultaneous acts: relinquishing claims to sovereignty and choosing to tolerate both external control and equalized rights to liberal freedom. By consenting to an external authority, the individual produces tolerance by transforming natural freedom into political liberty, guaranteed by laws and social rights.

As a central ordering principle of liberalism, tolerance seems to illustrate a permanent desire to maintain a cohesive political unit and protect individual claims to freedom. However, as the impact of liberalism grew and became more intertwined with capitalism, tolerance provided an avenue for repression. ${ }^{10}$ By limiting the extent of individual freedom, liberal polities produced a new form of tolerance that expects individual acceptance and subservience, a process that results in both inclusionary and exclusionary practices. To not tolerate means to produce another category; the intolerable who in physical manifestations often become an external other used to protect liberal values. Historically, this condition of repressive tolerance emerged distinct from the progressive tolerance "consented to" at the moment of political consent. While the latter describes tolerance as the recognition of an external authority consented to in order to protect subjective and economic freedom, the former suggests that liberal tolerance 
becomes a philosophical and political tool used to cement State power and justify the consequences of liberal-capitalism: economic disparity, environmental destruction, hierarchical political and social structures, etc, etc. ${ }^{11}$ At the subjective level, Marcuse, in a study on authority, envisions an irreconcilable duality that helps structure liberal tolerance: "the authority relationship [...] assures two essential elements in the mental attitude of he who is subject to authority: a certain measure of freedom (voluntariness: recognition and affirmation of the bearer of authority, which is not based solely on coercion) and conversely, submission, the tying of will (indeed of thought and reason) to the authoritative will of an Other." 12 This duality helps elucidate the ways in which subjective repression and external, environmental (natural, political, social, and cultural) destruction can be overlooked in liberal polities due to a narrowing of individual freedom, i.e. economic and personal liberty secured by an external State.

While Locke argues for liberty, he also argues for social control and manipulation through education/socialization, imagining "the minds of children as easily turned this or that way as water itself."13 This type of control illustrates that equality in the liberal sense means only equal access to individual and economic freedom; the State exists to protect this right, but seemingly does not exist to help realize economic and personal freedom at the subjective level. By elevating the protection of rights, tolerance becomes a means for extending State power as long as that power appears, in its action and functioning, to protect the liberal values of freedom. In this specific manifestation, liberal tolerance absolutely ignores the production of socioeconomic hierarchies and systems of entrenched power that naturally arise in capitalist-organized societies. Tolerance, as a perceived model of inclusion, structures the hierarchical relationship that in turn defines the extent and limits of tolerance.

During the 2010 Presidential State of the Union Address, President Barack Obama further problematized this conceptualization of liberal tolerance. In shifting from an international to domestic perspective, Obama states, "We find unity in our incredible diversity, drawing on the promise enshrined in our Constitution: the notion that we are all created equal, that no matter who you are or what you look like, if you abide by the law you should be protected by it; that if you adhere to our common values you should be treated no different than anyone else."14 While Obama issued this phrase in relation to greater civil 
rights and liberties, the comment reveals the potential for repressive tolerance to emerge as the operational ethos of liberalism. The quote explicitly establishes an "us vs. them" mentality, an essentialism that states if you follow "our common values" and "our" laws, then your identity is recognized and tolerated. However, what if you fall outside these definitions? What happens when tolerance, as defined here, functions within a liberal context, where celebrated values begin and end with individual and economic liberty? Once tolerance and economic freedom become permanently linked, the potential for abuses of power emerges, and the establishment of hierarchical structures socially, culturally and politically begins to become evident. Such a connection dictates tolerance according to economic participation and thus suggests that challenges cannot, nor should not, be tolerated.

When we consider this dictum in relation to the Lockean model of consensual governance, the State, specifically in the Western context, becomes the judge for those who fall within its protection. If economic activity and access become the liberal goals, the State protects economic interests by regulating those who do not "adhere to our common values." By categorizing those who belong and do not belong within the liberal polity, the State assumes pure sovereign absolutism capable of mandating levels and extensions of tolerance. Beginning with Carl Schmitt's sovereign authority and extending to more modern conceptions of a biopolitical state that regulates claims to inclusion and life, theorists such as Walter Benjamin, Michel Foucault, Giorgio Agamben and Judith Butler recognize the consequences: once the State assumes sovereign control, it maintains itself and the values it strives to protect through violence and exclusion - the State assumes full power to dictate political inclusion and political exclusion. ${ }^{15}$

For example, Agamben argues that during moments of exception or emergency, the sovereign authority may deny legitimate claims for protection and rights if, as Obama suggests, those individuals challenge the values and legal systems of the State. ${ }^{16}$ Benjamin goes a step further, arguing that "the tradition of the oppressed teaches us that the 'state of emergency' in which we live is not the exception but the rule" because, in this analysis, the State operates according to the volatility and challenges posed by the hyper-valuation of economic freedom. ${ }^{17}$ If liberalism and tolerance truly become interchangeable, then the State functions absolutely to repress challenges and maintain the virility of capitalist 
enterprises that may, and often do, include exploitation. This potentiality, for Herbert Marcuse, allows tolerance to become a philosophical approach and pragmatic method for (violently) repressing challenges to national values in order to maintain individual, capitalistic growth. Given this potential, Marcuse investigates the following question: if tolerance leads to systems of repression and avenues for pursuing unlimited State power (and violence), should the individual seek to resist or repress all repressive systems of tolerance?

\section{Developing a Solution: Herbert Marcuse and the One-Dimensional Society}

Marcuse thus emerges at this critical juncture to offer a critique of the equivocation of liberalism and tolerance. By linking individual and economic liberty with tolerance, tolerance loses its potential for progressive equality and freedom, serving rather to cement liberal values and the State that exists to protect it. In a broader application, Marcuse's work represents a radical reply to the stifling conditions of a post-WWII era he labeled "one-dimensional." 18 From ideas of play-based Eros to calls for political activism and engagement, Marcuse discerned a historical moment that, in vying for completion, functionally separated the individual from the aspects of living that should matter. The post-industrial society of the mid$20^{\text {th }}$ century achieved a rare ability to produce enough goods and sustenance for everyone $-\mathrm{a}$ post-scarcity world. However, rather than seek out new alternatives, the liberal-capitalist model sought to finalize this position of permanent producers and consumers, a new organizational ethos, as William Whyte foresaw, which bound the individual to a redundant and circulatory position: work to get more, get more by continually working. ${ }^{19}$

In Marcuse's analysis, society in the post-industrial age perpetuates its own existence rather than cultivating the individual experience; the emphasis changes from how society betters the individual to how the individual functions for, and is defined by, the external system. In order to cement this emphasis, the one-dimensional society substitutes personal needs with repressive needs in which the individual, according to Marcuse comes to "love and hate what others love and hate [...] [these needs] continue to be what they were from the beginning - products of a society whose dominant interest demands repression." ${ }^{20}$ Obscured behind the myth of liberty and affluence, society limits the individual according to technical rationality; the social system defines and dominates the conceptualization of self-worth and 
personal ability. Societal productiveness signals individual worth and value. Consequently the individual loses Eros, substituting the pleasure principle with the reality principle, which for Marcuse "implies the subjugation and diversion of the destructive force of instinctual gratification, of its incompatibility with the established societal norms and relations, and, by that token, implies the trans-substantiation of pleasure itself." ${ }^{21}$ Affectively defined and maintained by an external system, the post-industrial world replaced any internal sense of self with servitude to the system through the dual false promises of affluence and personal liberty.

Dedicated to permanent liberal-capitalist progress (because it is through progress that the capitalist machine permanently functions and expresses the economic freedom of the individual), the modern period is defined by Marcuse as the "mechanization and standardization of life"; effectively, the cementing of the historical moment, the perceived end of historical progress. ${ }^{22}$ Here Marcuse suggests that the State maintains control by appearing to function at the height, or end, of progress. Potentially transformative, the attachment to a progress promised by an external authority, the State, causes people to tolerate related notions that seem to comfort and secure. In and of itself, this is not absolutely problematic. But, when it begins to operate according to external structures and systems of economic control, the comfort and security felt within a progress-based society ultimately create the conditions for a tolerance that represses.

Yet the actual manifestations of repression remain veiled (at least in the collective consciousness) behind the liberal promise of economic and individual liberty for all. This dedication to common values allows an exploitative State and economic institutions to continue to display a great deal of real diversity. Returning to Obama, if we politically and socially accept those who adhere to "our common values," then the system is available to all. Yet the consequences of this veiled system of repression are endless. By appearing to tolerate diversity and a degree of minority opinions and positions (as long as the general liberal values remain apparent), the post-industrial society is able to propagate violence and repression while actually exhibiting real diversity - thus suggesting a repressive tolerance more totalitarian in application.

\section{A Conflicting Narrative: ("Non"-Repressive) Tolerance}


If liberal polities legitimate the extended use of State and economic power as long as it secures the safety and comfort of the tolerated (and tolerating) masses, liberal tolerance both secures diversity and negates non-adherents. For politicians seeking to justify the affects of war, economic hierarchies, and entrenched systems of power and control, tolerance makes, quoting Marcuse, "compulsory behavior with respect to established policies" by moving "from practice to non-practice," 23 from progressive inclusion and growth, to entrenched notions of control and power. While Marcuse's argument derives from an analysis of nuclear war, police action against subversive student movements, and the fight against communism, it corresponds strongly with the modern fight for freedom, the spread of democracy, and wars against terror when he states "violence and suppression are promulgated, practiced, and defended by democratic and authoritarian governments alike, and the people subjected to these governments are educated to sustain such practices as necessary for the preservation of the status quo."24

Here, Marcuse references a key relationship between the maintenance of the status quo and education. The bridge between maintaining hegemonic normalcy and pursuing ends that may not serve the interests of a nation is secured through an educational system that highlights the success of tolerance, i.e. Civil Rights, Women's rights, LGBT movement, and emphasizes how tolerance toward the political machine helps secure the common end. Americans learn to accept the political model as a set, embedded institution that includes various groups, but labels radical movements of change as intolerable because such groups may challenge the accepted values of the nation. In such a liberalized context, tolerance becomes the socio-cultural force needed to legitimate repressive political action. Dissent thus transforms into mere rhetoric exactly because the liberal world demands tolerance; tolerance no longer exists as a viable solution for procuring concrete, social transformation that moves beyond token gestures of inclusion. And, more importantly, when this transformation cannot be completed through incorporation, the State silences (intolerates) dissent by dehumanizing and depoliticizing the former subject. ${ }^{25}$

As a result, liberal tolerance equates with repression, negating any notion of experimental or autonomous engagement. For the individual agent, tolerance leads to a cascade of expectations that fundamentally define and limit an active citizenry to "support" the State and its course of action. Issues arise when this leads to the imprisonment and 
torture of "suspects" in the name of certain basic American values or when basic human rights are denied domestically and internationally in the name of a national cause. ${ }^{26}$ The average citizen tolerates pictures and stories of torture and false imprisonment abroad ${ }^{27}$ and homelessness and vast inequalities ${ }^{28}$ domestically because tolerance toward state-sponsored activities is expected of an engaged and liberal citizenry. Viewed critically, this allendorsing tolerance provides a sense of legitimacy to the State's extension into extra-legal forms of violence. In these moments, the dichotomy of the citizen (those who adhere to the State's values) vs. non-citizens (those who challenge the State's values) becomes solely the decision of the State. Seen here as an inclusive concept definitionally, tolerance becomes the means for exclusion pragmatically. Consequently, when Agamben describes the subjective reality of a suspended citizen (one dictated as outside the tolerance and rights of the State), he describes a subject "who may be killed and yet not sacrificed."29

In such an analysis, according to Marcuse, "tolerance is extended to policies, conditions, and modes of behavior which should not be tolerated because they are impeding, if not destroying, the chances of creating an existence without fear and misery. $" 30$ By recognizing the relationship between tolerance and actual liberal policies, Marcuse discerns how society negates the opportunity to seek out and realize different social ends by equivocating tolerance with policies and ideals created out a national sense of fear. Fear becomes an essential motivating force enabling the State to coerce and control the actions and even mindsets of the citizenry - by identifying the excluded "other," the State both increases its perceived commitment to liberal tolerance and cements the exclusionary nature of tolerance and the resulting differentiation of power and claims to violence. Functionally, tolerance motivates political actors into consensually-subjected positions, which in turn legitimizes the actions and directions of the State. In such a liberal context, tolerance becomes a means to an end: the ability to mobilize a country to pursue goals that may be distinct, and often contradictory, to the proclaimed values inherent to that country.

\section{Politics of Inclusion (?): Deliberative Practices, Tolerance and Systems of Power}

Modern American tolerance has consequentially lost its way, and in the process, wars, domestically and internationally, are pursued and legitimated through a process of 
tolerance. The West no longer associates tolerance solely with diverse lifestyles, but rather with the dictums of the liberal machine, trapping the subject and "former" subject within a system outside individual control - an entrapment both physical and mental. In this system, Marcuse asserts, "a mentality is created for which right and wrong, true and false are predefined wherever they affect the vital interests of the society." 31 Marcuse interprets liberal tolerance as a mechanism the State uses to define and narrow values, participation and political acceptance. By predefining the language of the system, "the avenues of entrance are closed to the meaning of words and ideas other than the established one, conclusively disengaging meaningful dissent aimed at transformation by sublimating (or eliminating) it into the system. Nowhere is this more evident than in the modern deliberative democracy movements, ${ }^{33}$ where inclusive policies seek to overcome power structures and majoritarian policies that may contradict the voice of the citizenry. ${ }^{34}$ Yet purely deliberative practices fail to recognize, as Marcuse points out, that such meetings are fixed in time and place. ${ }^{35}$ Those challenging the dominant values fail to procure change because the system denies the space for truly progressive politics of transformation, replacing these spaces and moments of transformation with acts of inclusion in order to maintain the status quo while cultivating an image of an all-encompassing, tolerance-based socio-political system.

By definition, deliberative democracy requires tolerance; it necessitates an avenue for the dissenting voice without necessarily empowering that voice. When such an avenue exists within the modes of language, systems of power, and entrenched hierarchies that define the nature of the engagement, true inclusion becomes a farce, and the voice of dissent becomes a whisper, lost amongst false premises and conceptualizations of public tolerance. In an analysis of activist action versus deliberative politics, Iris Marion Young demonstrates the inadequacies of a purely deliberative process: in a society "structured by deep social and economic inequalities [...] formally inclusive deliberative processes nevertheless enact structural biases in which more powerful and socially advantaged actors have greater access to the deliberative process and therefore are able to dominate the proceedings with their interests and perspectives." 36

In Young's analysis, deliberative processes in practice fail to recognize that inclusionary procedures in themselves do not respond to real hierarchical structures that 
empower, limit and exploit. However, because the structure of inclusion exists, an illusion of real and full democratic decision-making pervades a people, allowing those in power (a position derived from the sovereign capacity to define the nature of deliberative practices) to operate according to, and potentially beyond, inclusion and tolerance. As a result, the State secures unabridged legitimacy to pursue legal and extralegal policies under the guise that all voices have been heard (tolerance), the process produced a desired end and course of action (State now legitimized to use power and force to protect values), and the policy must be supported by the system due to the process (tolerance of the system/tolerance of the result).

In the name of tolerance, the dissenter becomes part of the system, allowing the State to pursue actions that expect the tolerance of the people, thus producing an endless circle of approval, regardless of the outcomes. In moments of extreme emergency, when incorporation is perceived as too limited a solution, the process of tolerance permits the State to move into unregulated boundaries of action to protect its vital interests and citizenry. An analysis of the state of exception leads Agamben to define these moments "as the establishment, by means of the state of exception, of a legal civil war that allows for the physical elimination not only of political adversaries but of entire categories of citizens who for some reason cannot be integrated into the political system. ${ }^{37}$ How else could we ignore (and as a result, tacitly legitimate) Abu Ghraib and the stories that emanate from Guantanamo? The answer lies in the modern, liberal use of tolerance: these instances and other images of violence are necessary (and should therefore be tolerated) in order to secure "our safety," pursue the "war on terror," and spread "freedom" and "democracy" throughout the world. By using language sincere to the hearts of Americans, the Bush administration created an environment that used objective stories, coupled with subjective reasoning, to produce a mission supported by its citizenry. The "enemy combatant," "terrorist" or any designated "other" become a referent for understanding the paradoxical nature of a liberal tolerance which includes/excludes, empowers/limits and, most importantly, dictates the accepted citizen and the excluded, dehumanized non-citizen.

Yet events throughout the "liberal world" do not solely indicate a blind adherence to liberal tolerance. The election of Barack Obama (which is not without its critics), the greater and more frequent expressions of dissent aimed against the Iraq War, and other 
signs of liberal-capitalism illustrate a growing resolve to deny the interchangeability of liberalism and tolerance and search out new means of existence. ${ }^{38}$ Engaging Marcuse's understanding of a reversed repressive tolerance helps shed light on the exacting nature of liberal tolerance and the difficulty of challenging tolerance as an ideal.

\section{Praxis of Reversal: Liberation through Repressive Tolerance}

For Marcuse, tolerance must extend beyond the reification of liberal action and values. In his analysis, tolerance can, and should, perpetuate spheres for subversion and dissent that challenge the continuation of entrenched systems of power and repression, thus providing space for liberation and personal exploration. In its liberal-capitalist manifestation, liberal tolerance emerged as the definitional principle of governance used to secure policy acceptance, resulting in the perpetuation of exclusionary practices. The modern neoconservative movement embodied by the Bush administration established negative practices that effectively ignored issues domestically and destroyed basic human rights internationally. Based on the often unfounded perception of vital threats against the safety of liberal values, recent politics, from preemptive military strikes to the expansion of torture techniques, demonstrate how tolerance for State action allows the State to expand into unregulated zones of action. These extralegal moments represent a split from the consent-based model of democratic practices, but find legitimacy in both the real and tacit acceptance of a body politic.

In an analysis of Guantanamo Bay and its resulting restriction of political identity and dehumanization of the intolerable other, Butler describes how

"in the name of a security alert and national emergency, the law is effectively suspended in both its national and international forms. And with the suspension of law comes a new exercise of state sovereignty, one that not only takes place outside the law, but through an elaboration of administrative bureaucracies in which officials now not only decide who will be tried, and who will be detained, but also have ultimate say whether someone may be detained indefinitely or not."39

With unlimited access to power and violence, the State operates through exclusionary principles, highlighting a duality of "protecting" a citizenry while essentially negating the voice of the citizen. Once tolerance loses its true focus, it becomes a political weapon for 
deciding the level and practice of political rights. As Butler warns, this ability to decide the nature of the "political life" (what it is and who it belongs to) bestows ultimate power on the State in deciding the actual nature of living: "some lives are grievable, and others are not; the differential allocation of grievability that decides what kind of subject is and must be grieved, and which kind of subject must not, operates to produce and maintain certain exclusionary conceptions of who is normatively human." 40 If the State assumes a monopoly on deciding the nature and extent of political inclusion, then tolerance, within a liberalcapitalist setting, fundamentally challenges the ideal, emancipatory nature of tolerance and determines categories of existence. Regaining the promise of tolerance and the ability to move forward with a progressive society that empowers the individual, demands, according to Marcuse, repressive tolerance aimed at the State or structures of power.

In 1965, Marcuse wrote, "liberating tolerance, then, would mean intolerance against movements from the Right, and toleration of movements from the Left." ${ }^{, 41}$ While mired in ideological debates over the nature of Western politics and society, Marcuse's critique ultimately recognizes the ways in which liberal politics, regardless of being practiced by the Right or Left, necessarily repress and exclude. In less ideological terms, Marcuse understands tolerance to mean the continual, non-repressive process for finding answers and courses of action outside liberal politics that seek to radically redefine what it means to be a democracy and a subject both nationally and internationally.

Rational, inclusive discussions limit the available ends, making actual intolerance toward prevailing systems of entrenched power potentially necessary. For Marcuse, tolerance would mean moving beyond the status quo by eliminating its traditional meaning (the interchangeability of tolerance and liberalism) and instituting a system of tolerance that challenges the capacity of the current status quo to blind and repress the true interests and values of the American people. Marcuse's essay then represents more than a simple attack on the modern meaning of tolerance; it demonstrates a concerted attempt to challenge the hegemony of liberal practices. Alone, traditional liberal politics can never provide an allencompassing answer or maintain inclusionary principles that do not simultaneously exclude. In order to respond to this process of political and subjective imprisonment, an active citizenry must be willing to step outside the bounds of tolerable actions to engage 
with new, non-liberal based understandings of tolerance that attempt to establish more communal and humanist projects.

Recognizing the repressive expansion of liberal-capitalist projects, Marcuse directly challenges the nature of modern tolerance: "when tolerance mainly serves the protection and preservation of a repressive society, when it serves to neutralize opposition and to render men immune against other and better forms of life, then tolerance has been perverted." ${ }^{22}$ Once perverted, tolerance loses its latent progressivism and its ability to challenge destructive ends. Once established as the operational ethos, Marcuse contends, perverted tolerance can only be undone by intolerance toward that very system. In a reversal of praxis, the emancipatory and non-exclusionary, inclusionary nature of tolerance become practical realities only if the repressive characteristic of liberal tolerance is itself repressed. For Marcuse, this intolerance begins by removing the false consciousness of tolerance that pervades the American system and mind, by relearning to "think in the opposite direction" in order to escape the tendency of placing "the facts into the predominant framework of values." ${ }^{, 43}$ The hierarchical structure of society uses tolerance to include the voice of dissent in order to disempower movements of radical change. Change becomes a concrete possibility when the systems and structures of a repressive State are challenged at the core, and the dissenting voice becomes not only tolerated, but tolerated as a movement to re-engage democratic idealism and tolerance in the modern age.

In an analysis of Locke, Michael Walzer writes, "any individual citizen, oppressed by the rulers of the state, has a right to disobey their commands, break their laws, even rebel and seek to replace rulers and change the laws" due to that very oppression. ${ }^{44}$ Distinct from the exclusionary/inclusionary definition of tolerance derived from his theory of liberalism, Locke strongly declares that an unjust government "may be questioned, opposed, and resisted, [if it] use[s] unjust force. ${ }^{, 45}$ Relying ultimately on a conceptual social contract, Locke argues for a socialized subject (one capable of operating in a liberalized context) and a subject who must act to protect the truly progressive nature of a democratically-organized society.

It is this great democratic tradition that makes Marcuse's essay as relevant today as it was in 1965. In the modern American setting, politicians pursue and achieve ends distinct from its democratic ideals and promises by engaging and advocating a system of inclusive 
tolerance that promotes entrenched systems of power at the cost of progressive change. To reinvigorate the progressive passions and ideals of the citizenry, tolerance must be seen for what it is and the promises it holds. The concept of progressive tolerance within a democratic polity necessitates, according to Marcuse, the "practice of discriminating tolerance in an inverse direction [...] tolerance would be restricted with respect to movements of demonstrably aggressive or destructive character. ${ }^{, 46}$ Never an end in itself, repressive tolerance seeks to regain the strength of American democracy: "the alternative to the established semi-democratic process is not dictatorship or elite, no matter how intellectual and intelligent, but the struggle for a real democracy $[\ldots]$ part of this struggle is the fight against an ideology of tolerance which, in reality, favors and fortifies the conservation of the status quo of inequality and discrimination."47

\section{Aggressive Liberation: The Problem with Repressive Tolerance}

However, Marcuse is not without his own faults and critiques. By advocating repressive policies, Marcuse runs the risk of obscuring his own message. In his earlier works, Marcuse highlights the possibility for Eros, play and aesthetics to define societal and political structures. Key to the development of real liberation, these Marcusian values respond against the hyper-mechanization of the post-industrial world and the repressive physical and psychological practices of the State. Yet by contrasting these values with essays and polemics aimed at repressive action, Marcuse fails to recognize the exacting relationship between ideal, humanist-based principles for existence and violent action. Can violence procure peaceful existence? And in what ways does repressive tolerance help the individual arise out of the liberal malaise and into communally-based, primary narcissism?

More pragmatically, at what point does reverse repression simply mimic or replicate the repressive character of liberal tolerance? Can repressive tolerance ever secure change without violent revolution? Placed in its unique historical context, the dormant violence of Marcuse's work becomes evident when connected ahistorically to, taking but one example, the vision of Vladimir Lenin's revolutionary fervor: "But what is forgotten or glossed over is this: if the state is the product of the irreconcilable character of class antagonisms, if it is a force standing above society and 'increasingly separating itself from it,' then it is clear that the liberation of the oppressed class is impossible not only without a violent revolution, 
but also without the destruction of the apparatus of state power, which was created by the ruling class and in which this 'separating' is embodied." ${ }^{48}$ While Lenin's Marxian perspective derives from an analysis of class antagonisms, his call for direct and violent engagement with a State apparatus that functions above society equates with Marcuse's critique of liberal practices. While Lenin's “dictatorship of the proletarian” can be debated, his emphasis on establishing a vanguard party that functions outside the repressed class fails, much like Marcuse' emphasis on repression, to recognize the violent and repetitive character of new models of hierarchy. Can one model of hierarchy replace another without replicating basic, negative characteristics, namely systems of entrenched power and claims to violence that perverted tolerance to begin with?

Viewed historically, as the 1960s bear out, a shift from working within the system to direct, violent clashes with the State helped obscure the emancipatory and transcendent nature of 1960 s radicalism. ${ }^{49}$ Rather than creating zones of real tolerance, the repressive tolerance of 1960 s radicals was met with greater intolerance from the State. The battle essentially changed from one of values, to asserting dominance and control. Yet even this narrative is not clean, and it would be ill-conceived to limit the perceived end of the 1960s to a faulty shift into violence. Indeed, the shift to violence by 1960 s radicals was not absolute, and represented but one effort in a myriad of efforts to change the system. As Marcuse's analysis develops, repressive tolerance in practice can never exist in perpetuity, but arises from within the collective voice of a people unwilling to remain within a repressive system buttressed by the interchangeability of liberal values and tolerance. Even if we accept that Marcuse's repressive tolerance exists only in relation to State repression and ideally dissipates as State repression dissolves, it remains unclear how tolerance can regain its progressive nature without consistently resorting to exclusionary practices and repression.

\section{From Tolerance to Repression and Back}

While the concept of repressive tolerance may seem distinct to democratic values or may result in replicating the repressive system currently in place, the reality lies deeper in its true value to democratic processes and ideals. In practice, tolerance becomes a sociopolitical tool needed to pursue progressive ends and ideals. A purely liberal tolerance that 
leads to the maintenance of the status quo and entrenched systems of power misses the point; tolerance means accepting the distinct views of a multicultural society while pursuing practices that realize the grand promises and utopic quality of the American project. It cannot, nor should not, function as a way to justify hierarchical systems or processes of inclusion and exclusion. If necessary, repressive tolerance conceivably provides the modern political agent with an approach for challenging and overcoming the current system in order to seek a new end; it means recognizing repressive systems of power as illegitimate and therefore something that cannot be ipso facto tolerated.

The goal as Marcuse concludes is "universal tolerance [...] practiced by the rulers as well as the ruled, the lords as well as by the peasants, by the sheriffs as well as their victims." ${ }^{50}$ In its current manifestation, liberal tolerance ignores entrenched systems of power and structural inequalities by relegating the scope of tolerance to the State; by controlling the extent of tolerance, the State ultimately controls the mechanisms that promise and protect political life. Marcuse's shift into repressive tolerance does not arise solely to destroy the State, but to challenge the restricted liberal definition of tolerance in order to make tolerance a universal principle that negates the capacity of the State or specific individuals or institutions to repress. In the end, if the status quo use of liberal tolerance leads to repression and destruction, then liberal tolerance should be withdrawn, and repressive tolerance, with the goal of realizing democratic ideals and universal tolerance that forever destroy systems of repression, should be engaged.

\section{Notes}

\footnotetext{
${ }^{1}$ Herbert Marcuse, "Repressive Tolerance" in Critique of Pure Tolerance, ed. Robert Paul Wolff, Barrington Moore, Jr., and Herbert Marcuse (Boston: Beacon Press, 1969), 81.

${ }^{2}$ Rodney Fopp, "Herbert Marcuse's 'Repressive Tolerance' and his Critics," Borderlands e-journal, 6, no. 1 (2007): 5. http://www.borderlands.net (accessed July 9, 2008).

${ }^{3}$ See The Gallup Poll, "Gallup's Pulse of Democracy: The War in Iraq." http:/www.gallup.com/poll/1633/Iraq.aspx (accessed July 2, 2008); Dana Milbank and Jim VandeHei, "No Political Fallout for Bush on Weapons," Washington Post, Saturday, May 17, 2003, page A01.

${ }^{4}$ Marcuse, "Repressive Tolerance," 83.

${ }^{5}$ Louis Hartz illustrates the difficulties of narrowing liberalism to a single definition. See Ch. 1. Louis Hartz, The Liberal Tradition in America (New York: A Harvest Book, 1955). While this paper understands liberalism in its latter stages, specifically in its connection to capitalism and the elevation of economic freedom, others argue for a more progressive, socially-oriented understanding of liberalism. In 1911, L.T.
} 
Hobhouse's book Liberalism established a progressive understanding of liberalism in which the individual sacrifices ultimate freedom to the State who in return assumes an active role in helping in obtaining freedom by providing access to food, shelter, education and protection from exploitation. See L.T. Hobhouse,

Liberalism (Oxford: Oxford University Press, 1964).

${ }^{6}$ Marcuse, "Repressive Tolerance," 11.

${ }^{7}$ John Locke, Two Treatises of Government, ed. Peter Laslett (Cambridge: Cambridge University Press, 1988), 283.

${ }^{8}$ Thomas Hobbes, Leviathan, ed. C.B Macpherson (London: Penguin Books, 1985), 186.

${ }^{9}$ Locke, Two Treatises of Government, 209.

${ }^{10}$ While it may seem simplistic to intertwine liberalism and capitalism, Locke's model of private property and the relation to economic liberty pave the way for later, more free-market and limited freedom liberals to establish arguments in favor of a liberalism defined by its capitalistic nature and restriction of absolute liberty. See Locke, Two Treatises of Government, 285-302; Adam Smith, The Wealth of Nations (New York: Bantam Classics, 2003); Kenneth Arrow's General Possibility Theorem; Herbert Spencer, The Man Versus the State (LOCATION: Liberty Fund Inc., 1982); F. A. Hayek, The Road to Serfdom (Chicago: University of Chicago Press, 1994); John Kenneth Galbraith, The Affluent Society (New York: Houghton Mifflin, 1958).

${ }^{11}$ For arguments against liberalism see Mao Zedong, Combat Liberalism (Peking University, 1954); Michael J. Sandel, Liberalism and the Limits of Justice (Harvard University, 1998); Michael J. Sandel, Liberalism and its Critics (Harvard University, 1984); Stephen D. Krasner, Structural Conflict: The Third World Against Global Liberalism (Stanford University, 1985); Martha Craven Nussbaum, The Feminist Critique of Liberalism (Chicago: University of Chicago, 1997).

${ }^{12}$ Herbert Marcuse, A Study on Authority, trans. Joris De Bres (London: Verso, 1972), 7.

${ }^{13}$ John Locke, Some Thoughts Concerning Education and Of the Conduct of the Understanding, ed. Ruth W. Grant and Nathan Tarcov (Indianapolis, IN: Hackett Publishing Company, Inc., 1996), 10.

${ }^{14}$ Barack Obama, State of the Union Address, January 27, 2010.

${ }^{15}$ See Carl Schmitt, Political Theology (Chicago: The University of Chicago Press, 2005); Giorgio Agamben, Homo Sacer: Sovereign Power and Bare Life (Palo Alto, CA: Stanford University Press, 1998); Giorgio Agamben, State of Exception, trans. Kevin Attell (Chicago: The University of Chicago Press, 2005); Judith Butler, Precarious Life: The Powers of Mourning and Violence (London: Verso, 2004); Michel Foucault, The Foucault Affect: Studies in Governmentality. Ed. Graham Burchell, Colin Gordon and Peter Miller (Chicago: University of Chicago Press, 1991); Walter Benjamin, Illuminations, ed. Hannah Arendt, trans. Harry Zohn (New York: Schocken Books, 1968), 257.

${ }^{16}$ In moments of crisis, the State, according to Schmitt, may suspend normal political rights and obligations and assume extra-legal power (hence, extra-legal violence) to respond to an exception to normal governance: "the exception, which is not codified in the existing legal order, can at best be characterized as a case of extreme peril, a danger to the existence of the state, or the like" that allows the State, when necessary, to "violate such commitments, to change laws or to suspend them entirely according to the requirements of a situation, a time, and a people" (Political Theology, 6, 9). In response to Schmitt, Agamben outlines the actual manifestation of this condition "as the establishment, by means of the state of exception, of a legal civil war that allows for the physical elimination not only of political adversaries but of entire categories of citizens who for some reason cannot be integrated into the political system" (State of Exception, 2).

${ }^{17}$ Benjamin, Illuminations, 257.

${ }^{18}$ Herbert Marcuse, One-Dimensional Man (Boston: Beacon Press, 1964).

${ }^{19}$ In his analysis of the organizational man, William Whyte grasped that by the 1950s, American society had fully established an ethos that "rationalizes the organization's demands for fealty and gives those who offer it wholeheartedly a sense of dedication in doing so [...] it converts what would seem in other times a bill of no rights into a restatement of individualism." In William Whyte, The Organization Man (Philadelphia: The University of Pennsylvania Press, 2002), 6.

${ }^{20}$ Marcuse, One-Dimensional Man, 5.

${ }^{21}$ Herbert Marcuse, Eros and Civilization (Boston: Beacon Press, 1966), 13.

${ }^{22}$ Marcuse, Eros and Civilization, 3.

${ }^{23}$ For a discussion of justice, oppression, and entrenched power structures, see Iris Young, Justice and the Politics of Difference (Princeton University Press, 1990); Marcuse, "Repressive Tolerance," 82.

${ }^{24}$ Marcuse, "Repressive Tolerance," 82. 
${ }^{25}$ In Agamben's analysis of the state of exception, he highlights the distinction between bare life and political life and the ways in which the sovereign power may dictate the creation of Homo Sacer, a former subject who may be killed, but never mourned or sacrificed. See Agamben, Homo Sacer, 3-4, 8, 28, 51-52, 139.

${ }^{26}$ See Jane Mayer, The Dark Side: The Inside Story of How the War on Terror Turned into a War on American Ideals (Doubleday, 2008); Scott Higham and Joe Stephens, "New Details of Prison Abuse Emerge," Washington Post, May 21, 2004, (accessed July 10, 2008); Adam Hochschild, "What's in a Word? Torture," New York Times, May 23, 2004 (accessed July 10, 2008).

${ }^{27}$ See Philippe Sands, Torture Team: Rumsfeld's Memo and the Betrayal of American Values (New York: Palgrave Macmillan, 2008); Marnia Lazreg, Torture and the Twilight of Empire: From Algiers to Baghdad (Princeton University Press, 2007); Elizabeth Holtzman, “Torture and Accountability," The Nation, June 28, 2005 (accessed July 7, 2008); Josh White, "Officer acquitted of mistreatment in Abu Ghraib Case," The Boston Globe, August 28, 2007 (accessed July 8, 2008).

${ }^{28}$ See Jonathan Kozol, Savage Inequalities: Children in America's Schools (New York: Crown Publishers, 1991); Jonathan Cohn, Sick: The Untold Story of America's Health Care Crisis-and the People Who Pay the Price (New York: HarperCollins, 2007); Sicko, Director Michael Moore, DVD, Weinstein Company, 2007; Barbara Ehrenreich, Nickel and Dimed: On (Not) Getting By in America (New York: Metropolitan Books, 2001); David Shipler, The Working Poor: Invisible in America (London: Vintage, 2005).

${ }^{29}$ Agamben, Homo Sacer, 8.

${ }^{30}$ Marcuse, "Repressive Tolerance," 82.

${ }^{31}$ Marcuse, "Repressive Tolerance," 95.

${ }^{32}$ Marcuse, "Repressive Tolerance," 96.

${ }^{33}$ Amy Gutmann and Dennis Thompson, Democracy and Disagreement (Cambridge, Belknap Press, 1998).

${ }^{34}$ Iris Marion Young, "Activist Challenge to Deliberative Democracy," Political Theory, Vol. 29, No. 5, October 2001, 670-90.

${ }^{35}$ Marcuse, "Repressive Tolerance," 90-1, 93-4.

${ }^{36}$ Young, "Activist Challenge to Deliberative Democracy," 679.

${ }^{37}$ Agamben, State of Exception, 2.

${ }^{38}$ See "Approval for Iraq Handling Drops to New Low," CNN, December 18, 2006 (accessed July 3, 2008); Dalia Suusman, "Poll Shows View of Iraq War is Most Negative Since Start," The New York Times, May 25, 2007, (accessed July 11, 2008): Greg Newbold, "Why Iraq Was a Mistake," Time Magazine, April 9, 2006 (accessed July 9, 2008); Steve Vogel and Clarence Williams, "Rousing, Emotional Start for War Protest," The Washington Post, March 17, 2007, B01 (accessed July 9, 2008); Patrick Tyler, "A New Power in the Streets," The New York Times, February 17, 2003 (accessed July 3, 2008).

39 Judith Butler, "Indefinite Detention," Precarious Life: The Powers of Mourning and Violence (London: Verso, 2004), 51.

${ }^{40}$ Butler, Preface, Precarious Life, xiv-xv.

${ }^{41}$ Marcuse, "Repressive Tolerance," 109.

${ }^{42}$ Marcuse, "Repressive Tolerance," 111.

${ }^{43}$ Marcuse, "Repressive Tolerance," 113.

${ }^{44}$ Michael Walzer, "The Obligation to Disobey," Obligations: Essays on Disobedience, War and Citizenship (Cambridge: Harvard University Press, 1970), 3.

${ }^{45}$ John Locke, Two Treatises of Government, 403.

${ }^{46}$ Marcuse, "Repressive Tolerance," 119, 120.

${ }^{47}$ Marcuse, "Repressive Tolerance," 123.

${ }^{48}$ V.I. Lenin, State and Revolution (New York: International Publishers, 1934), 9-10.

${ }^{49}$ For example, the main organization from the New Left, Students for a Democratic Society (SDS), experienced a direct rift in organizational tactics and principles. Once dedicated to non-violent demonstrations with the State (what one could argue as an extension of deliberative practices), SDS splintered over revolutionary tactics and aims. Pursuing Marxian and post-colonial theoretical avenues for redress, the SDS ultimately broke apart, leaving in its place a grab-bag of political activism and revolutionary forces, key of which being the Weathermen, later the Weather Underground. Using Marxist rhetoric, the Weather Underground advocated direct, violent engagement with the State; in Marcusian terms, the Weather Underground and other late-1960s revolutionary forces sought out repressive tolerance in order to challenge and transform the nature of tolerance, achievable for majority of these groups solely through violence. For a history of the New Left, SDS and the Weather Underground, see Terry Anderson, The Movement and the 
Sixties: Protest in America from Greensboro to Wounded Knee (Oxford: Oxford University Press, 1995); Stanley Aronowitz, The Death and Rebirth of American Radicalism (New York: Routledge, 1996); James Miller, Democracy is In the Streets: From Port Huron to the Siege of Chicago (New York: Simon and Schuster, 1987); Doug Rossinow, The Politics of Authenticity: Liberalism, Christianity, and the New Left in America (New York: Columbia University Press, 1998); Todd Gitlin, The Sixties: Years of Hope, Days of Rage (New York: Bantam Books, 1993); Jeremy Varon, Bringing the War Home: The Weather Underground, The Red Army Faction, and Revolutionary Violence in the Sixties and Seventies (Berkeley: University of California Press, 2004). For bibliographic recollections and analyses of repressive, revolutionary practices in the 1960s, see the following memoirs: Bill Ayers, Fugitive Days: Memoirs of an Anti-war Activist (Boston: Beacon Press, 2008); Mark Rudd, Underground: My Life with SDS and the Weathermen (New York: William Morrow Press, 2009); Cathy Wilkerson, Flying Close to the Sun: My Life and Times as a Weatherman (St. Paul, MN: Seven Stories Press, 2007); David Gilbert, SDS/WUO, Students For A Democratic Society And The Weather Underground Organization (Montreal, Quebec: Abraham Guillen Press \& Arm the Spirit, 2002).

${ }^{50}$ Marcuse, "Repressive Tolerance," 84. 